\title{
The effect of crop rotation and fertilization on wheat and maize in the pedoclimatic conditions of the Banat Plain
}

\author{
Borza Iacob, Cseke-Kreppel Ludovic, Dragoş Cosmin, Gaica Ioan, Iordache Mădălina \\ University of Agricultural Sciences and Veterinary Medicine of Banat, Timisoara, Romania \\ iacobborza@yahoo.com
}

Key words: monocultivation, crop rotation, mineral and organic fertilization, cambic gleyed chernozem, yield

SUMMARY

The simplification of the plant cultures range and the yields in the last 10-15 years brings into the actuality the role of crop rotation and of fertilization on the yield level and stability for wheat and maize even on the soils with a high natural fertility. The results of the researches performed between the years 2006 - 2009 on a cambic low gleyed chernozem from the Banat Plain showed that the wheat cultivated in monoculture gives productions with 59-81\% lower than that cultivated in crop rotation with other plants during 2-4 years. In maize, the yield obtained in monoculture is situated behind that obtained in crop rotation with 11-21\%. The most favorable crop rotations for wheat were rape-wheat in a 4 years rotation and soybean-wheat in simple rotation of 2 years. In maize, the most favorable was the 2 years rotation (wheat-maize). The mineral fertilization was very efficient both in wheat (11-36\%) and maize (9-31\%). The organic fertilization with manure was very efficient for maize, the yields being superior with a mean value by $34 \%$ for a 60 t/ha dose and with $16 \%$ for $30 t / h a$. The fertilization compensates the negative effect expressed by the monocultivation only in a small measure.

\section{INTRODUCTION}

In the last 10-15 years it can be observed a reduction of the plant number that is cultivated in all countries of Europe and in an accentuated way in Romania (Borza and Coste, 2002; Borza et el., 2006; Marinca et al., 2009). The main cause is represented by the express demand for cereals (wheat and maize) required by the animal breeding complexes in relation with the continuing decreasing animal effectives from the household system (Borza and Coste, 2002; Marinca et al., 2009).

In the condition of a decreasing number of the plant cultures within the vegetal farms to only 3-4 plants, their rotation was simplified to an interval by $2-4$ years and the monocultivation is performed on at least $25-30 \%$ surfaces for wheat and $30-40 \%$ for maize. In monocultivation, there is relying on the mineral fertilization contribution, in augmented amounts, and on the phytosanitary treatments, with much larger costs. The research results, as well as those found in production showed that even when the fertilization is increased, the monoculture is under crop rotation with up to $30-50 \%$ from yield in wheat and in a small measure in maize (Borlan et al., 1999; Borza et el., 2006).

On the soils with low natural fertility and in the years with less favorable climatic conditions for wheat crop, the yield results obtained in monocultivation are totally unsatisfactory.

The organic fertilization is performed on extremely reduced surfaces, and in many farms is excluded because of the orientation of the agriculture system to the animal breeding in large complexes by industrial type. The relinquishment to the organic fertilization of the agricultural lands puts in danger their fertility even in the condition of a well balanced mineral fertilization (Borlan et al., 1999; Borza et el., 2006; Marinca et al., 2009; Țărău et al., 2008).

The climatic conditions with accentuated droughty tendency necessitate to adapt the tillage technologies to this specific feature (Marinca et al., 2009; Popa and Borza, 2008; Popa and Borza, 2007; Țăău et al., 2008).

\section{MATERIAL AND METHODS}

The researches were carried out during the years 2006-2009 on a cambic low gleyed chernozem within the Didactic Station of the University of Agricultural Sciences and Veterinary Medicine of Banat (USAMVB) from Timişoara, Romania, the soil being representative for approx. 10-15\% of Banat Plain.

The experiments, in number of two, are stationary, with the following factors and ranges: crop rotations and various doses of mineral fertilizers, respectively crop rotations and increasing doses of manure.

For wheat, there were cultivated autochthon kinds, and for maize there were cultivated Pioneer hybrids.

The mineral fertilization was realized with ammonium nitrate and complexes fertilizers 1:1:0 and 1:1:1, and the organic fertilization with semi-fermented manure from the bovine farm, applied before the maize cultivation.

The yield results are related to the STAS humidity, respectively $14 \%$ for wheat and $15 \%$ for maize, and the data processing was made by analysis of the variance with appropriate soft.

The researches continued in the year of 2010 and in the next years it is intended to be monitored not only the yields, but the soil fertility evolution too, as a consequence of the systematic application of the mineral and organic fertilizers. 


\section{RESULTS AND DISCUSSION}

The characteristics of the cambic low gleyed chernozem from the Didactic Station of the (USAMVB) Timişoara, in the experimental location, were identified by opening a soil profile and can be found in the table 1 .

Table 1

The chemical, physical and hydrophysical characteristics of the cambic low gleyed chernozem, medium clay-loamy (medium clay-loamy) from the Didactic Station of USAMVB Timişoara

\begin{tabular}{|c|c|c|c|c|c|c|c|c|}
\hline Pedological horizon & Ap & Atp & Am & AB & BC & CCA g & CCA g & CCA g \\
\hline Depth & $0-20$ & $20-35$ & $35-50$ & $50-65$ & $65-85$ & $85-110$ & $110-130$ & $130-200$ \\
\hline $\mathrm{pH}$ in water & 6.00 & 6.60 & 6.70 & 6.90 & 7.75 & 8.10 & 8.15 & 8.25 \\
\hline $\mathrm{CaCO}_{3}$ & - & - & - & - & 0.60 & 15.50 & 17.70 & 10.80 \\
\hline Humus & 2.97 & 2.79 & 2.42 & 2.23 & 1.73 & 0.93 & - & - \\
\hline Nitrogen index & 2.58 & 2.48 & 2.20 & 2.11 & 1.73 & - & - & - \\
\hline $\mathrm{P}_{\mathrm{AL}}(\mathrm{ppm})$ & 35.0 & 7.2 & 6.7 & - & - & - & - & - \\
\hline $\mathrm{K}_{\mathrm{AL}}(\mathrm{ppm})$ & 322.0 & 262.3 & 259.8 & - & - & 100 & - & - \\
\hline $\mathrm{V}_{\mathrm{AH}}(\%)$ & 87.0 & 89.0 & 91.2 & 94.9 & 100 & 41.0 & 100 & 100 \\
\hline Clay $(<0.002 \mathrm{~mm})$ & 44.1 & 43.1 & 45.4 & 45.0 & 45.3 & & 39.0 & 44.9 \\
\hline
\end{tabular}

The $\mathrm{pH}$ has values between 6 in the Ap horizon and 6,7 in the Am horizon, fact that indicates a low acid reaction in the first $50 \mathrm{~cm}$ topsoil, the humus supplying in the Ap horizon is good, the phosphorous supplying is middle to good $(35 \mathrm{ppm})$, the potassium supplying is very good in the Ap horizon (322 ppm), the apparent density is $1,54 \mathrm{~g} / \mathrm{cm}^{3}$ which shows an advanced compaction degree, and the total porosity is by $38,65 \%$ which denotes a compacted soil. Generally, the soil has a high fertility potential.

After the capability classification was settled that the studied soil is framed in the class of 61-80 points, being favorable both for wheat and maize. As fertilization requirements it reclaims the periodical application of the manure and an annually chemical fertilization in moderate and balanced doses, with special attention to the nitrogen-phosphorous ratio.

Under climatic aspect, the researched area is characterized by a multiannual mean temperature by $10.9{ }^{\circ} \mathrm{C}$ and a precipitation sum by $623 \mathrm{~mm}$ (Meteorological Station Tiumişoara). In the experimental years 2006-2009 there were registered differences both regarding the multiannual means and for each year (table 2).

The climatic characteristics of the years 2006-2010 related to the multiannual means (Meteorological Station Timişoara)

\begin{tabular}{|c|c|c|c|c|}
\hline Agricultural year & $\mathbf{T}\left({ }^{\circ} \mathrm{C}\right)$ & Deviations & $\mathbf{P}(\mathbf{m m})$ & Deviations \\
\hline 2006 & 10.8 & -0.1 & 705 & +182 \\
\hline 2007 & 13.1 & +2.2 & 518 & -105 \\
\hline 2008 & 11.9 & +1.0 & 730 & +107 \\
\hline 2009 & 12.0 & +1.1 & 525 & -98 \\
\hline Multiannual mean & \multicolumn{2}{|c|}{10.9} & 623 & \\
\hline
\end{tabular}

Under thermal aspect, in three consecutive years $(2007,2008,2009)$, the annual mean temperature exceeded the normal value, and in one year (2006) it was near to the multiannual mean.

Under pluviometrical aspect, in two years (2006 and 2008) the normal value was exceeded, and the two others (2007 and 2009) were more droughty than usually.

Related to the climatic requirements of the two plant cultures, the year of 2006 was slightly favorable for wheat and favorable for maize, the year of 2007 was favorable for wheat and slightly favorable for maize, the year of 2008 was favorable for wheat and very favorable for maize, and the year of 2009 was very favorable both for wheat and maize. Statistically, it was found that in the four studied years there were slightly favorable conditions only in a single year for wheat (2006) and maize (2007) and very favorable conditions in one year for wheat (2009) and in two years for maize (2008 and 2009).

The analysis of the yield results depending on the experimental factors that were studied (crop rotation and fertilization) shows significant aspects which lead to valuable scientific and practical conclusions.

In wheat, the mean yields for four research years oscillated between 2083 and $5208 \mathrm{~kg} / \mathrm{ha}$, varying with the crop rotation and with the applied fertilization (table 3). Comparing to the monocultivation, the crop rotation by 2 and 4 years increased the wheat yiled with $1497-2076 \mathrm{~kg} / \mathrm{ha}$, respectively with $59-81 \%$. The most favorable rotation was that of 4 years when the wheat followed after rape. In the 2 years rotation, the wheat behavior was the same after soybean and respectively after maize, excepting the unfertilized variant where the soybean proved that is superior to the maize as a precursory plant for wheat.

The effect of the crop rotation and mineral fertilization on wheat $(\mathrm{kg} / \mathrm{ha})$ between the years 2006-2009

\begin{tabular}{|c|c|c|c|c|c|c|}
\hline \multirow{2}{*}{ Crop rotation } & \multicolumn{7}{|c|}{ Fertilization } \\
\cline { 2 - 7 } & $\mathrm{N}_{0} \mathrm{P}_{0} \mathrm{~K}_{0}$ & $\mathrm{~N}_{60} \mathrm{P}_{0} \mathrm{~K}_{0}$ & $\mathrm{~N}_{60} \mathrm{P}_{60} \mathrm{~K}_{0}$ & $\mathrm{~N}_{120} \mathrm{P}_{60} \mathrm{~K}_{0}$ & $\mathrm{~N}_{120} \mathrm{P}_{60} \mathrm{~K}_{60}$ & Mean \\
\hline Monocultivation & 2083 & 2375 & 2660 & 2827 & 2920 & 2573 \\
\hline Wheat-maize & 3276 & 3794 & 4025 & 4585 & 4673 & 4070 \\
\hline Wheat-soybean & 3536 & 3820 & 4156 & 4588 & 4697 & 4159 \\
\hline
\end{tabular}




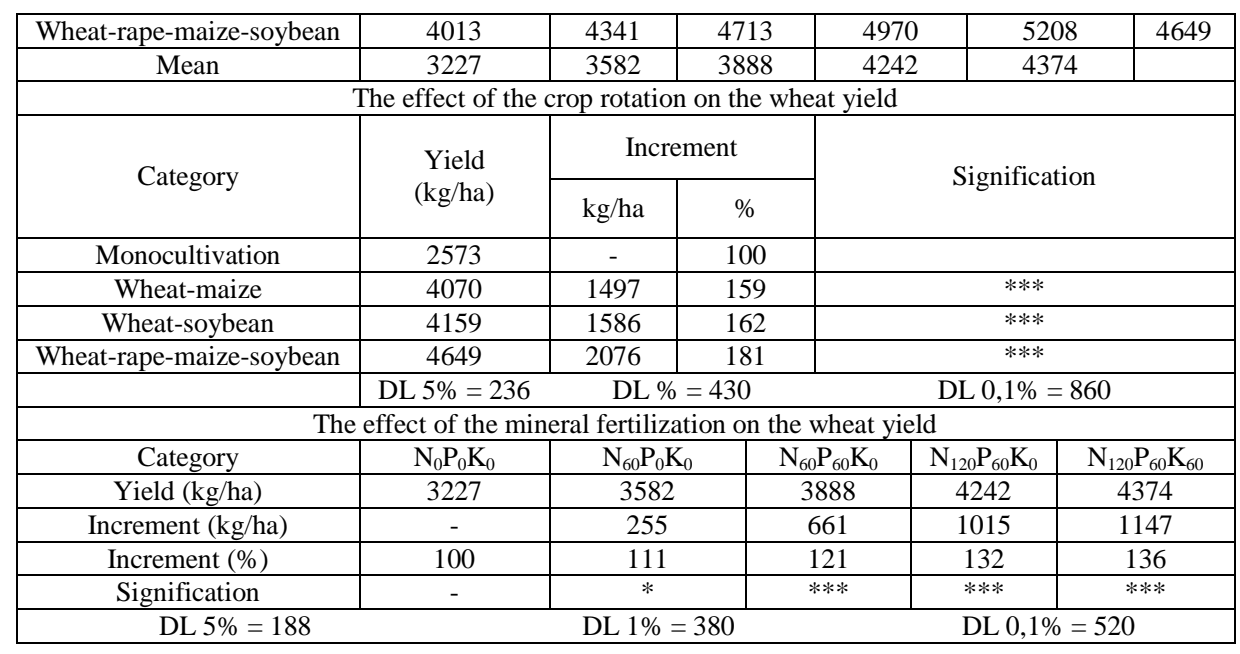

The yield results on years show that the wheat production in monocultivation decreased after the second cultivation year, even if this is appropriately fertilized (figure 1).

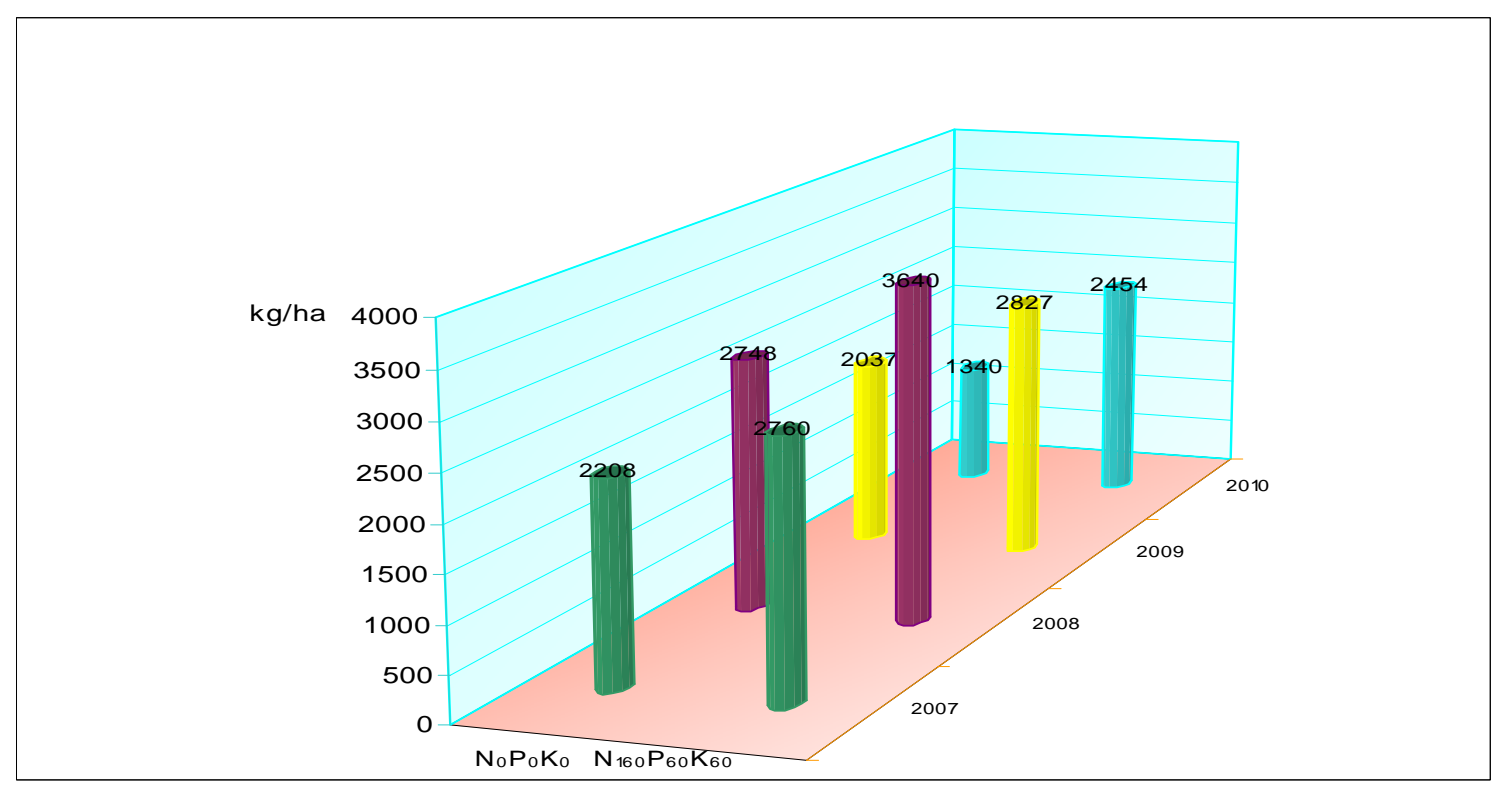

Figure 1: The evolution of the wheat yield in monocultivation

The effect of the mineral fertilization consisted of wheat yield increasing with $255-1147 \mathrm{~kg} / \mathrm{ha}$, respectively with $11-36 \%$. The effect of the nitrogen applied all-alone was small (11\%), but it was more significant in the presence of the phosphorous (2:1 ratio) and potassium (2:1:1). The optimal fertilization variant for wheat was $\mathrm{N}_{120} \mathrm{P}_{60} \mathrm{~K}_{60}$ for which there were registered a mean production in four years by $4585 \mathrm{~kg} / \mathrm{ha}$ in the 2 years rotation after the maize, $4588 \mathrm{~kg} / \mathrm{ha}$ in the 2 years rotation after the soybean and $4970 \mathrm{~kg} / \mathrm{ha}$ in the 2 years rotation after the rape. In maize, it was found a positive influence on the yield both of the crop rotation and fertilization (table 4).

The effect of the crop rotation and mineral fertilization on maize $(\mathrm{kg} / \mathrm{ha})$ between the years 2006-2009

\begin{tabular}{|c|c|c|c|c|c|c|}
\hline \multirow{2}{*}{ Crop rotation } & \multicolumn{6}{|c|}{ Fertilization } \\
\hline & $\mathrm{N}_{0} \mathrm{P}_{0} \mathrm{~K}_{0}$ & $\mathrm{~N}_{60} \mathrm{P}_{0} \mathrm{~K}_{0}$ & $\mathrm{~N}_{60} \mathrm{P}_{60} \mathrm{~K}_{0}$ & $\mathrm{~N}_{120} \mathrm{P}_{60} \mathrm{~K}_{0}$ & $\mathrm{~N}_{120} \mathrm{P}_{60} \mathrm{~K}_{60}$ & Mean \\
\hline Monocultivation & 5408 & 5780 & 6006 & 6500 & 7050 & 6148 \\
\hline Maize-soybean & 5920 & 6317 & 6674 & 7224 & 7900 & 6807 \\
\hline Maize-wheat & 6460 & 7115 & 7295 & 7860 & 8250 & 7396 \\
\hline Maize-soybean-wheat-rape & 5860 & 6360 & 7010 & 7290 & 7680 & 6840 \\
\hline Mean & 5912 & 6393 & 6746 & 7218 & 7720 & \\
\hline \multicolumn{7}{|c|}{ The effect of the crop rotation on the maize yield } \\
\hline \multirow{2}{*}{ Category } & \multirow{2}{*}{$\begin{array}{c}\text { Yield } \\
(\mathrm{kg} / \mathrm{ha})\end{array}$} & \multicolumn{2}{|c|}{ Increment } & \multirow{2}{*}{\multicolumn{3}{|c|}{ Signification }} \\
\hline & & $\mathrm{kg} / \mathrm{ha}$ & $\%$ & & & \\
\hline
\end{tabular}




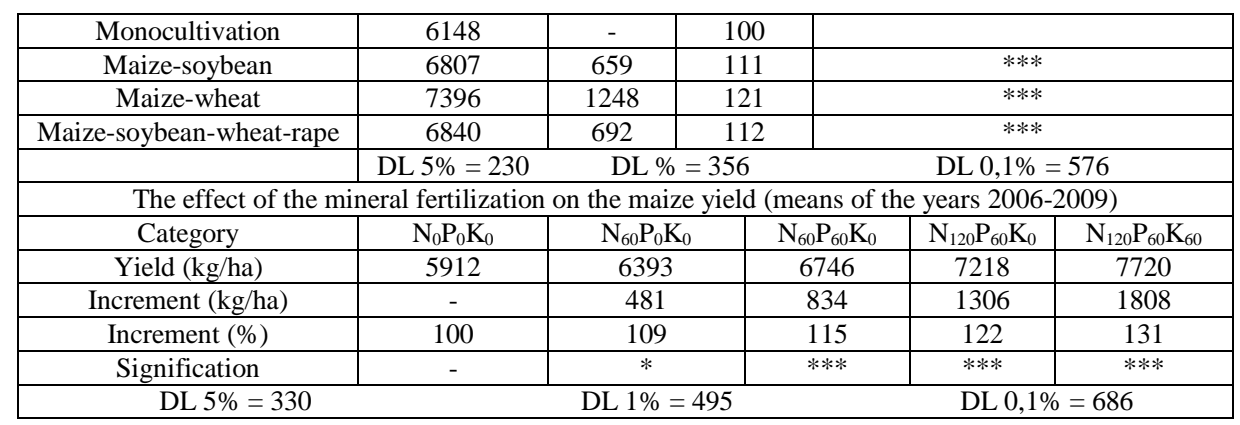

Related to the monocultivation, the rotations of 2 and 4 years proved to be more favorable, being obtained mean growths comprised between $659-1248 \mathrm{~kg} / \mathrm{ha}$, respectively by $11-21 \%$. The most favorable proved to be the 2 years rotation which has as precursory plant the wheat. The soybean, as precursory for the wheat assured a production increase by $11-12 \%$ in the rotations of 2 years and respectively 4 years. It can be remarked that the maize production in monocultivation did not decreased, the yield differences between the researched years were determined by the climatic conditions (figure 2).

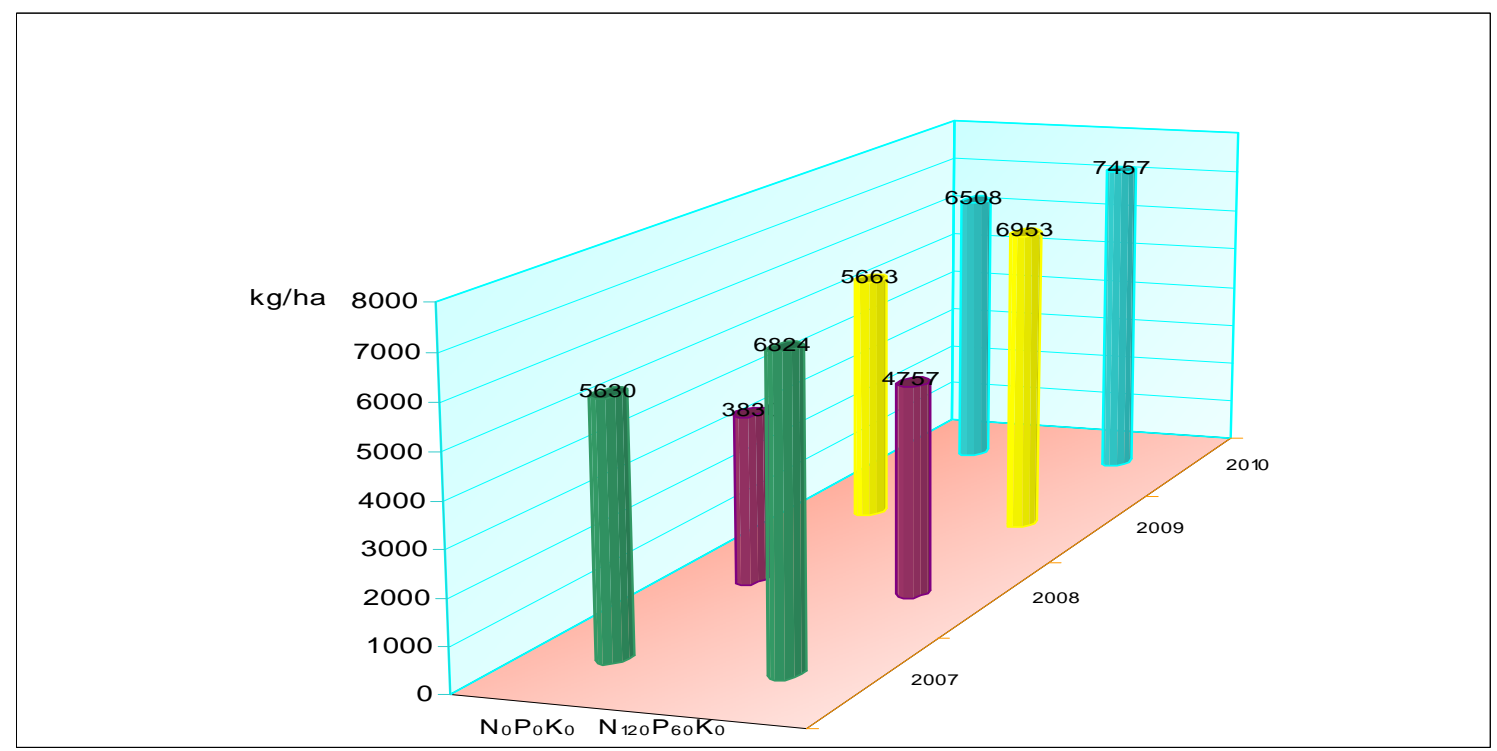

Figure 2: The evolution of the maize yield in monocultivation

The mineral fertilization led to the maize yield increasing with $481-1808 \mathrm{~kg} / \mathrm{ha}$ (growth by $9-31 \%$ ) related to the fertilization level. The nitrogen applied all-alone determined an increasing by $481 \mathrm{~kg} / \mathrm{ha}(9 \%)$. Very significant yield growths were registered only at large doses of nitrogen in combination with phosphorous $\left(\mathrm{N}_{120} \mathrm{P}_{60}\right)$ and with potassium $\left(\mathrm{N}_{120} \mathrm{P}_{60} \mathrm{~K}_{60}\right)$ for which the increasing are by $22 \%$ and respectively $31 \%$.

The organic fertilization with manure applied to the maize proved that it is very efficient, being obtained mean yield growths by 992 and $2064 \mathrm{~kg} / \mathrm{ha}$ at 30 and $60 \mathrm{t}$ manure/ha (table 5).

The effect of the crop rotation and organic fertilization on maize $(\mathrm{kg} / \mathrm{ha})$ between the years 2006-2009

\begin{tabular}{|c|c|c|c|c|}
\hline \multirow{2}{*}{ Crop rotation } & \multicolumn{4}{|c|}{ Manure (t/ha) } \\
\hline & 0 & 30 & 60 & Mean \\
\hline Monocultivation & 5970 & 6720 & 7460 & 6716 \\
\hline Maize-soybean & 6476 & 7458 & 8520 & 7484 \\
\hline Maize-wheat & 6732 & 7840 & 8858 & 7810 \\
\hline Maize-soybean-wheat-rape & 5614 & 6742 & 8213 & 6856 \\
\hline Mean & 6198 & 7190 & 8262 & \\
\hline \multicolumn{5}{|c|}{ The effect of the crop rotation on the maize yield (means of the years 2006-2009) } \\
\hline \multirow{2}{*}{ Category } & Yield & \multicolumn{2}{|c|}{ Increment } & \multirow{2}{*}{ Signification } \\
\hline & $(\mathrm{kg} / \mathrm{ha})$ & $\mathrm{kg} / \mathrm{ha}$ & $\%$ & \\
\hline Monocultivation & 6716 & - & 100 & - \\
\hline Maize-soybean & 7484 & 768 & 112 & **** \\
\hline Maize-wheat & 7810 & 1094 & 117 & **** \\
\hline Maize-soybean-wheat-rape & 6856 & 140 & 102 & **** \\
\hline
\end{tabular}




\begin{tabular}{|c|c|c|c|}
\hline \multicolumn{4}{|c|}{ The effect of the organic fertilization on the maize yield (means of the years 2006-2009) } \\
\hline Category & 0 & 30 & 60 \\
\hline Yield (kg/ha) & 6198 & 7190 & 8262 \\
\hline Increment (kg/ha) & - & 992 & 2064 \\
\hline Increment (\%) & 100 & 116 & 134 \\
\hline \multirow{2}{*}{ Signification } & - & $* * *$ & $* * *$ \\
\cline { 2 - 4 } & DL 5\% $=305$ & DL 1\%=512 & DL 0,1\% $=786$ \\
\hline
\end{tabular}

Although the maize monoculture does not represent a favorable technological solution, it can be remarked that, even in these conditions, the mineral and organic fertilization lead to yield increasing. The fertilizers efficacy is superior in the rotations of 2 and 4 years comparing to the monocultivation and it is preferable because the maize yields are much higher.

\section{CONCLUSIONS}

1. The climatic conditions from the Banat Plain between the years 2006-2007 were slightly favorable for wheat in the year of 2006 and for maize in the year of 2007, and in the rest of the years these were favorable and very favorable.

2. In conditions of the simplification of the range plant that are cultivated, the crop rotation becomes an extremely important production factor, especially for the wheat culture.

3. The wheat monoculture practiced for four years proved to be un-recommendable, although it was sustained by an appropriate fertilization, because the yield started to decrease from a year to another.

4. The maize monoculture, although it did not register yield decreasing, similarly to the wheat, is situated under the levels given by the rotation of 2 and 4 years.

5. The effect of the mineral fertilizers applied in the wheat or maize monoculture is attenuated comparing to the variant where the maize and the wheat are enclosed into a crop rotation.

6. All rotation variants that had been studied were superior to the monocultivation and determined very significant yield growths, both for wheat and maize.

7. The mineral and organic fertilization contributes to the yield increasing with $11-36 \%$ for wheat and with 9-34\% for maize. The optimal variant of mineral fertilizer application is $\mathrm{N}_{120} \mathrm{P}_{60} \mathrm{~K}_{0}$, and there is required the introduction of a dose of $60 \mathrm{~kg} \mathrm{~K}_{2} \mathrm{O} / \mathrm{ha}$ in order to maximize the yield.

8. The periodical organic fertilization applied to the maize represents a safe solution to increase the yield and the soil fertility.

\section{REFERENCES}

1. Borlan Z.-Ştefănescu Daniela-Alexandrescu Adriana-Nebunelea Dobrița (1999): Fertilizarea în cadrul unor sisteme de producție vegetală durabilă, Revue Stiința solului, vol. 33, no. 2 .

2. Borza I.-Coste I. (2002): Agroecologie şi dezvoltare agricolă durabilă, Eurobit Publishing House, Timişoara, Romania.

3. Borza I.-Puşcă I.-Țărău D. (2006): Calitatea solurilor din vestul României şi rezultate ale aplicării îngrăşămintelor chimice pe soluri şi la plante diferite, Proceedings of the International Symposium CIEC, Bacău, Romania, Agris Publishing House, Bucharest.

4. Marinca C.-Dumitru M.-Borza I.-Ţărău D. (2009): Solul şi fertilitatea, relația cu sistemele agricole din Banat, Mirton Publishing House, Timişoara, Romania.

5. Popa Veronica-Borza I. (2008): Results of the studies on the causes favoring the desertification risk in the Banat Plain, Proceedings of the International Symposium of USAMVB Timişoara, Faculty of Agriculture, vol. 40 (1), Agroprint Publishing House, Timişoara, Romania.

6. Popa Veronica-Borza I. (2007): The analysis of multiannual variation of temperature and precipitation related to the desertification risk in the Banat Plain, Proceedings of the International Symposium of USAMVB Timisoara, Faculty of Agriculture, vol. 39, Agroprint Publishing House, Timișoara, Romania

7. Țărău D.-Borza I.-Iordache Mădălina-Dicu D., 2008 - The influence of agrometeorological conditions on some agroecosystems components from the Vinga Plain in no-till cultivation system, Proceedings of the International Symposium of USAMVB Timişoara, Faculty of Agriculture, vol. 40, Agroprint Publishing House, Timişoara, Romania. 